\title{
SLEDOVI PLEISTOCENSKE POLEDENITVE STARE GALIČICE, MAKEDONIJA
}

\author{
dr. Uroš Stepišnik, dr. Karel Natek, Manja Žebre, Gregor Fabekovič, \\ Valentina Pajk, Simon Koblar, Dunja Ropret, Aljaž Šimon \\ Oddelek za geografijo, Filozofska fakulteta Univerze v Ljubljani \\ Aškerčeva 2, SI-I000 Ljubljana \\ e-mail: uros.stepisnik@gmail.com,karel.natek@guest.arnes.si
}

Izvirni znanstveni članek

COBISS 1.01

\section{Izvleček}

Gorski masiv Stare Galičice je bil v pleistocenu izrazito preoblikovan z ledeniškim delovanjem. Na podlagi detajlnega morfografskega kartiranja ledeniških oblik je bil določen obseg poledenitve, ki je bil veliko večji kot ga navaja predhodna literatura. Osrednji del gorskega masiva je prekrival ledeni pokrov, od katerega so navzdol odtekali odtočni ledeniki. $\mathrm{Na}$ podlagi morfometričnih analiz sledov poledenitve je bila ugotovljena ravnovesna meja viška zadnje poledenitve na nadmorski višini $1840 \mathrm{~m}$.

Ključne besede: pleistocen, poledenitev, snežna meja, Galičica, Makedonija

\section{REMNANTS OF PLEISTOCENE GLACIATION ON STARA GALIČICA MOUNTAIN, MACEDONIA}

\begin{abstract}
The Stara Galičica Mountain was highly reshaped by glacial processes during the Pleistocene. Based on the detailed morphographical mapping of glacial features, the extent of glaciation was determined as being far larger than described in previous references. The inner part of the massif was covered with an ice-cap from where outlet glaciers were flowing out. On the basis of morphometrical analysis of glacial features, the altitude of the glacier equilibrium line during the Last Glacial Maximum was established at $1840 \mathrm{~m}$ a.s.l.
\end{abstract}

Key words: Pleistocene, glaciation, equilibrium line altitude (ELA), Galičica, Macedonia 


\section{I.UVOD}

Planina Galičica leži v jugozahodnem delu Makedonije med Ohridskim in Prespanskim jezerom. Je razpotegnjena v smeri sever-jug, dolga okoli $50 \mathrm{~km}$, v najožjem delu znaša razdalja med obema jezeroma okoli $10 \mathrm{~km}$. Del masiva južno od prevala Ponce $(1568 \mathrm{~m})$ se imenuje Stara Galičica in presega nadmorsko višino 2000 m. Najvišji vrh se dviga na makedonsko-albanski meji (2265 m), nekoliko severneje je med planinci bolj poznan vrh Magaro (2254 m).

Stara Galičica ima značilne visokogorske poteze; povprečni nakloni pobočij so med $20^{\circ}$ in $50^{\circ}$, mestoma presegajo celo $70^{\circ}$ (Kolčakovski, 1996). Velika nadmorska višina pogojuje tudi podnebne značilnosti: povprečna julijska temperatura $10,5^{\circ} \mathrm{C}$ na nadmorski višini 2065 m podnebje najvišjih delov Stare Galičice po Köppenovi klimatski klasifikaciji uvršča v tip D (Kolčakovski, 1996). Na okoliških meteoroloških postajah izstopajo jesenski viški padavin. Letna količina padavin z nadmorsko višino narašča, od približno $700 \mathrm{~mm}$ na meteorološki postaji Ohrid (nadmorska višina 706 m) do okoli 1200 mm v višinskem pasu od 1200 do 1400 m (Kolčakovski, 1996).

Geološko predstavlja Galičica tektonski čok iz kamnin triasne starosti, ki sega od Grčije na jugu prek Albanije do Stogova na severu (Anđelković, 1988). Tektonsko dvignjeno območje Galičice ločuje višje ležečo tektonsko kotanjo Prespanskega jezera (853 m n.v.) od nižje ležeče tektonske kotanje Ohridskega jezera (695 m n.v.). Območje Galičice se tektonsko dviguje s povprečno hitrostjo okoli $5,5 \mathrm{~mm} /$ leto, medtem ko se sosednji kotanji ugrezata (Anđelković, 1988).

Masiv Galičice v veliki večini gradijo masivni apnenci zgornjetriasne starosti, debeline od 400 do $500 \mathrm{~m}$. Spodnje plasti sestavljajo spodnjetriasni konglomerati, ki so narinjeni na starejše kamnine (Kolčakovski, 1996). Predvsem severna in vzhodna pobočja gradijo paleozojski skrilavci in peščenjaki ter terciarni klastiti. Ponekod se pojavljajo tudi magmatske in metamorfne kamnine: na jugozahodu, ob albanski meji, najdemo leče serpentinita, peridotita, diabaza in gabra jurske starosti, na severovzhodnih pobočjih pa so leče devonskih globočnin, med katerimi prevladujeta sienit in granodiorit. Ob jugozahodni obali Prespanskega ter ob jugovzhodni obali Ohridskega jezera so prisotni kvartarni jezerski in rečni sedimenti, na pobočjih pa pobočni grušč in ledeniško-rečni nanosi. Prek celotnega masiva potekajo prelomi, najpogosteje v smeri S-J (Osnovna geološka karta SFRJ, lista Ohrid in Podgradec, 1977).

V okviru naše raziskave smo detajlno preučevali geomorfne oblike, ki so vezane na ledeniško preoblikovanje. Cilj raziskave, pri kateri je sodelovala skupina študentov z ljubljanskega Oddelka za geografijo, je bil izdelati rekonstrukcijo obsega poledenitve ob višku zadnje ledene dobe ter ugotoviti takratne paleoklimatske razmere. Za ugotavljanje obsega poledenitve je bila izdelana morfografska karta ledeniških erozijskih in akumulacijskih oblik (slika 1). Kartiranje je potekalo izključno na terenu, rezultat je morfografska karta območja v merilu 1 : 25.000, ki je bila osnova za izdelavo rekonstrukcije obsega poledenitve. S pomočjo kartografskega gradiva in s terenskimi meritvami smo zbrali osnovne morfometrične podatke o obsegu in debelini nekdanjih ledenikov ter na njihovi podlagi izdelali paleoklimatsko rekonstrukcijo. 


\section{PREGLED PRETEKLIH RAZISKAV NA OBMOČJU GALIČICE}

S speleološkimi značilnostmi območja in kraškimi oblikami so se ukvarjali Točkovski (1970), kasneje še Manaković, Andonovski in Kolčakovski (1993). Preučevano območje je obsegalo zahodna pobočja Galičice in obale Ohridskega jezera. Stojadinković (1968) se je ukvarjal z geološkim razvojem Ohridskega jezera in okolice. Območje jezera naj bi tako nastalo kot sinklinala, kar naj bi potrjevala tudi starost kamnin. O geomorfoloških značilnostih visokogorskega krasa so pisali Zikov (1987) in Kolčakovski (1995). Zikov (1987) je za potrebe prostorske ureditve narodnega parka Galičica pisal o geomorfoloških posebnostih območja ter o tukajšnjih posebnih živalskih in rastlinskih vrstah. Prav pestrost živalstva in rastlinstva naj bi bila razlog za ustanovitev narodnega parka. Kolčakovski (1995) je v pregledu obsega in oblik periglacialnega reliefa v Republiki Makedoniji na območju Galičice identificiral poligonalna tla, potujoče skale, nivacijske kotanje in polzenje tal.

Najcelovitejšo geomorfološko raziskavo območja Stare Galičice je objavil Kolčakovski (1996). Obravnava vrhnji del planine med prevalom Ponce in albansko mejo. Poleg opisa tektonike, podnebja in naklonov opisuje tudi značilne reliefne oblike. Ugotavlja, da na Stari Galičici prevladujejo kraški, fluviokraški in periglacialni relief ter fosilni ledeniški relief. V članku obravnava tudi paleoklimatske značilnosti Stare Galičice. Višino snežne meje v času zadnje poledenitve je določil na nadmorski višini med 1750 in 1900 m; metode, s katero je prišel do tega rezultata, $v$ članku ne pojasni. Ledenik naj bi se iz dveh krnic pod vrhom Magaro stekal do prevala Ponce, kjer naj bi bilo odloženo najnižje morensko gradivo. Danes naj bi na Galičici prevladovale vrtače in zakrasele rečne doline, zaradi trenutnih klimatskih razmer pa potekajo tudi periglacialni procesi (Kolčakovski, 1996).

\section{SLEDOVI LEDENIŠKEGA PREOBLIKOVANJA IN REKONSTRUKCIJA POLEDENITVE}

Z morfografskim kartiranjem območja smo identificirali številne akumulacijske in erozijske ledeniške oblike. Med najbolj tipičnimi erozijskimi ledeniškimi oblikami sta nedvomno dve krnici na severovzhodnem pobočju vrha Magaro. Poleg njih v vrhnjem delu območja prevladuje ledeniško obrušeno površje z mnogimi ledeniškimi grbinami. V dolinah na severnem delu območja smo identificirali tudi ledeniška ramena. Pogoste so tudi akumulacijske oblike, predvsem bočne in talne morene. Nekatere kotanje so zapolnjene tudi z drobnimi naplavinami, ki so rezultat podledeniškega spiranja, ali pa so bile kotanje zapolnjene šele $\mathrm{v}$ holocenu, po umiku ledenika. S pomočjo izdelane morfografske karte smo naredili rekonstrukcijo viška zadnje poledenitve.

Ob višku zadnje poledenitve je osrednji del Stare Galičice prekrival ledeni pokrov, ki se je proti jugu stekal prek vzhodnega pobočja, ki danes leži na albanski strani meje, v smeri Prespanskega jezera. Na severu, vzhodno od najvišjega vrha Magaro, se je ledeni pokrov iztekal v dva odtočna ledenika, ki sta segala vse do prevala Ponce. Celoten ledeni pokrov je bil v srednjem delu z vmesnim grebenom (arête) razdeljen na večji zahodni in manjši vzhodni del. Pokrov, ki je dosegal debeline tudi do 100 m, je prekrival vršni del masiva do nadmorske višine $2100 \mathrm{~m}$. Na zahodni strani arêta je večja kotanja, v katero so podledeniški 
Slika 1: Morfografska karta ledeniških oblik Stare Galičice z rekonstrukcijo obsega poledenitve ob višku zadnje ledene dobe

Figure 1: Morphographical map of glacial landforms on Stara Galičica with the reconstruction of glaciers during the Last Glacial Maximum

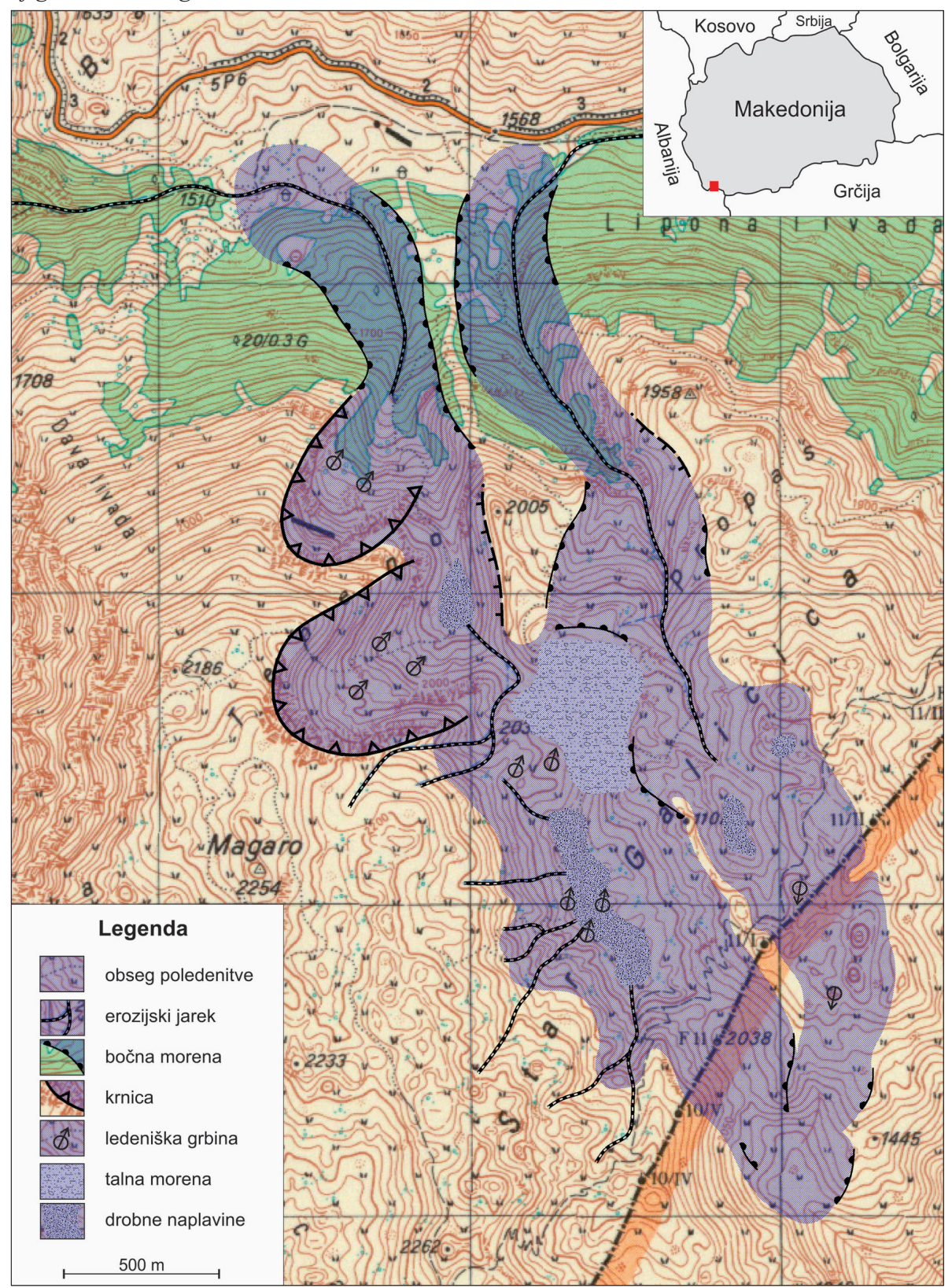


tokovi z zahodnega pobočja nasuli drobnozrnato naplavino. Dolžina uravnane naplavine, ki je na nadmorski višini $2030 \mathrm{~m}$, je okoli $600 \mathrm{~m}$ in širina približno $120 \mathrm{~m}$. Z zahodne strani vanjo vodi večje število erozijskih jarkov. V tej kotanji so tudi številne ledeniške grbine, s položnejšim delom na južni strani, kar nakazuje smer polzenja ledenega pokrova. Tudi na vzhodni strani arêta sta dve manjši kotanji, zapolnjeni z drobnozrnatimi naplavinami. Ena ima dolžino $215 \mathrm{~m}$ in širino $85 \mathrm{~m}$, druga $100 \mathrm{~m}$ in $80 \mathrm{~m}$. Severno od grebena se nahaja obsežnejše območje talnih moren. Na njihovem severnem robu je $350 \mathrm{~m}$ dolga bočna morena, ki označuje začetek odtočnega ledenika (slika 2). Na celotnem površju, preoblikovanem $\mathrm{z}$ delovanjem ledenega pokrova, poleg finozrnatih naplavin, morenskega gradiva in ledeniških grbin, najdemo tudi številne erozijske jarke. Nekateri od njih so aktivni, nekateri so delovali že v času poledenitve kot odtočni kanali podledeniških voda, saj so delno zapolnjeni s talnomorenskim gradivom.

Slika 2: Okoli 350 metrov dolga bočna morena na severni strani ledenega pokrova, ki omejuje območje talnih moren v ospredju (foto: $M$. Žebre)

Figure 2: About $350 \mathrm{~m}$ long lateral moraine on the northern rim of Pleistocene ice cap delimiting the area of ground moraines in the foreground (photo: M. Žebre)

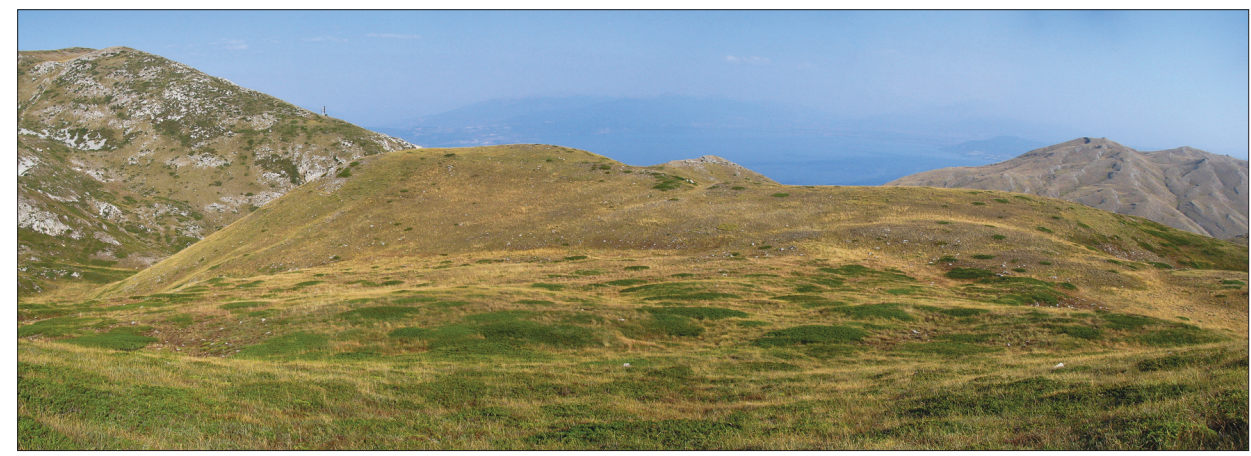

Led se je iz osrednjega ledenega pokrova stekal v dveh ločenih odtočnih ledenikih v smeri severa proti prevalu Ponce. Zahodni ledenik je poleg ledu iz ledenega pokrova dobival led tudi iz dveh krnic na zahodnem pobočju doline. Večja in višja krnica je na višini $2050 \mathrm{~m}$, nižja pa na 1900 m. V vrhnjem delu doline zahodnega odtočnega ledenika med obema krnicama se na nasprotnem pobočju nahaja izrazita ledeniška rama, na podlagi katere lahko ugotovimo, da je bila debelina odtočnega ledenika v tem delu okoli $80 \mathrm{~m}$. Vzhodni odtočni ledenik je v zgornjem delu doline nasul izrazite bočne morene, ki kažejo, da je bila debelina tega ledenika okoli $70 \mathrm{~m}$. Na pobočju južno od prevala Ponce so ohranjene izrazite bočne morene, ki označujejo največji obseg obeh odtočnih ledenikov ob višku zadnje poledenitve. Zahodni odtočni ledenik se je zaključil na nadmorski višini 1530 m, vzhodni pa na 1560 m. Po osrednjem delu dolin obeh odtočnih ledenikov potekata erozijska jarka, ki sta v času poledenitve odvajala podledeniške in predledeniške vodotoke. Potoki, ki so odtekali proti Ohridskemu in Prespanskemu jezeru, so v spodnjih delih pobočij nasuli rečno-ledeniške vršaje. 
Slika 3: Osrednji del Stare Galičice, ki je bil preoblikovan z ledenim pokrovom (foto: U. Stepišnik) Figure 3: Central part of Stara Galičica reshaped by Pleistocene ice-cap (photo: U. Stepišnik)

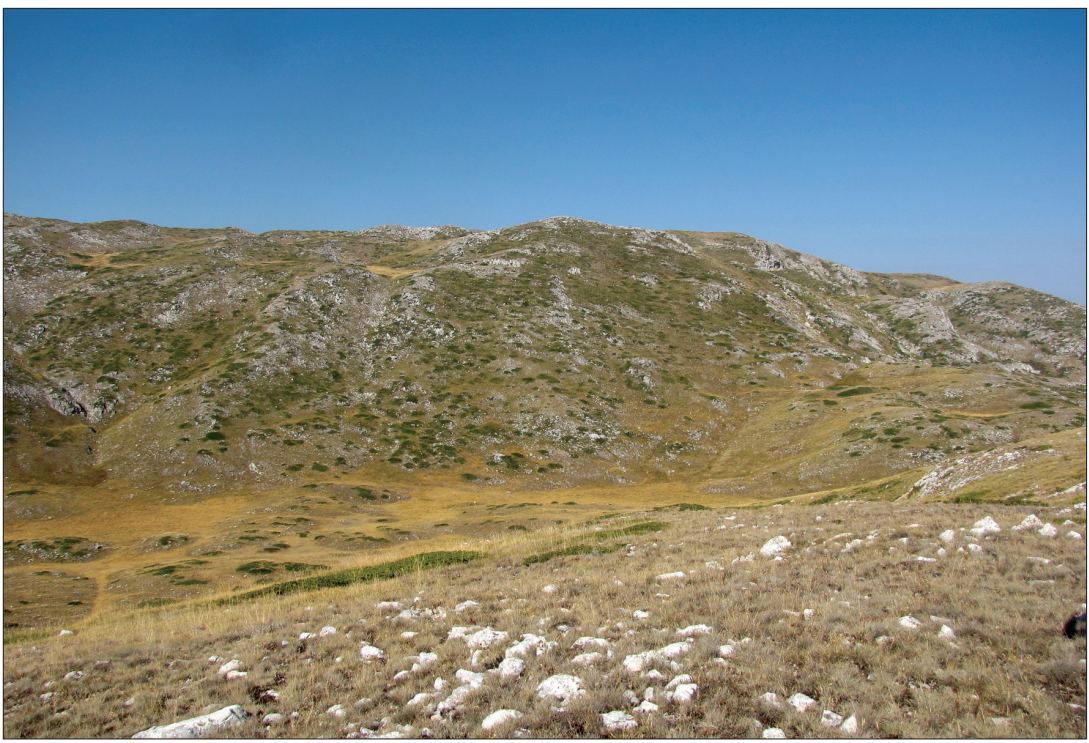

Slika 4: Bočne morene na prevalu Ponce, ki označujejo največji obseg obeh odtočnih ledenikov ob višku zadnje poledenitve (foto: $M$. Žebre)

Figure 4: Lateral moraines on Ponce Pass delimiting the maximum extent of outlet glaciers during the Last Glacial Maximum (photo: M. Žebre)

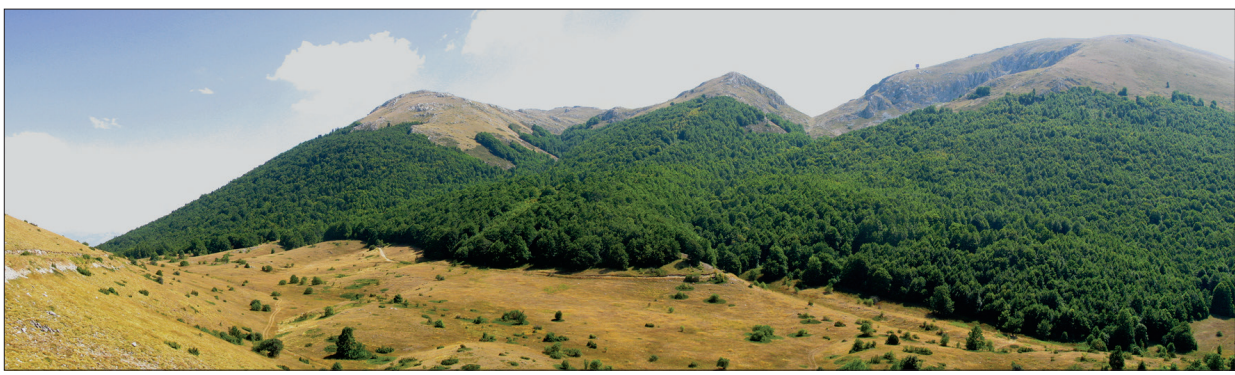

$\mathrm{Na}$ jug je led iz obeh delov ledenega pokrova, zahodnega in vzhodnega, odtekal $\mathrm{v}$ dveh odtočnih ledenikih. Debelina zahodnega odtočnega ledenika je bila okoli 50 m, vzhodnega pa okoli $30 \mathrm{~m}$. V zgornjih delih dolin obeh odtočnih ledenikov najdemo danes ledeniško obrušeno površje z ledeniškimi grbinami, v njunih spodnjih delih so ohranjeni tudi deli bočnih moren. Oba odtočna ledenika sta se na pobočju združila v enoten ledeniški jezik, ki se je zaključil na uravnanem delu vzhodnega pobočja Stare Galičice na nadmorski višini okoli 1380 m. 
Slika 5: Krnica v pobočju nad nekdanjim zahodnim odtočnim ledenikom (foto: U. Stepišnik)

Figure 5: A cirque on the slopes above the Pleistocene western outlet glacier (photo: U. Stepišnik)

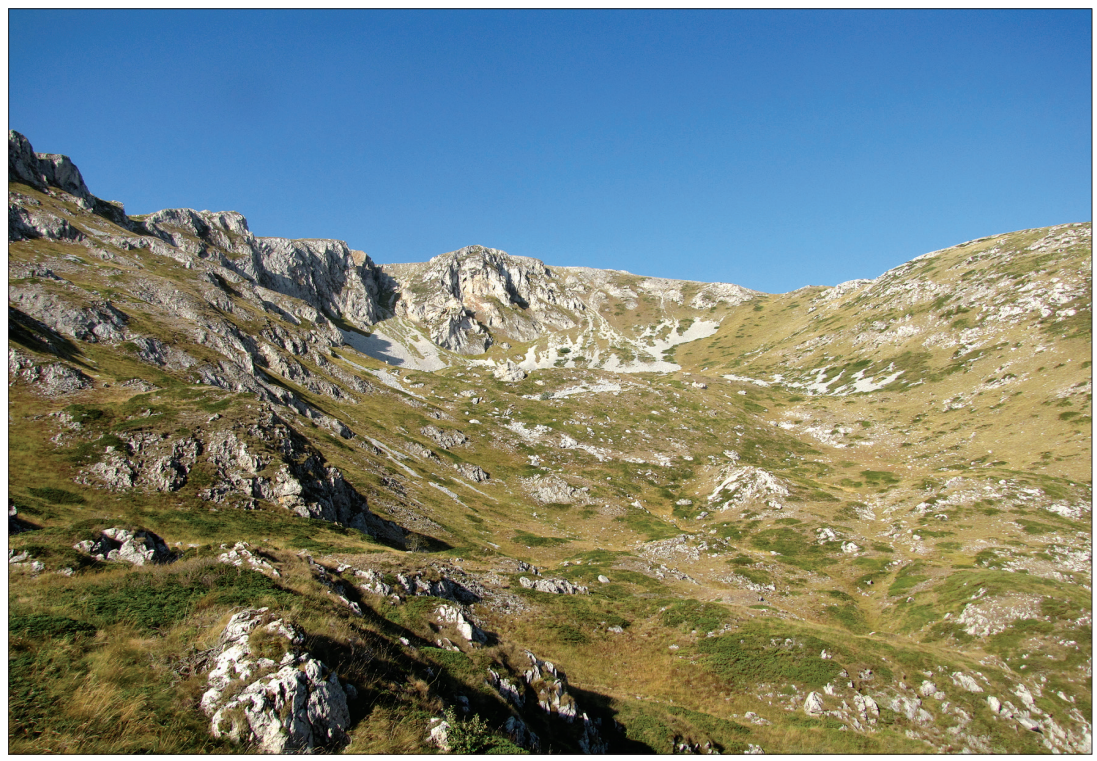

Slika 6: Erozijski jarek v zgornjem delu doline vzhodnega odtočnega ledenika (foto: U. Stepišnik) Figure 6: A gully in the upper part of the valley filled with the eastern outlet glacier during the Last Glacial Maximum (photo: U. Stepišnik)

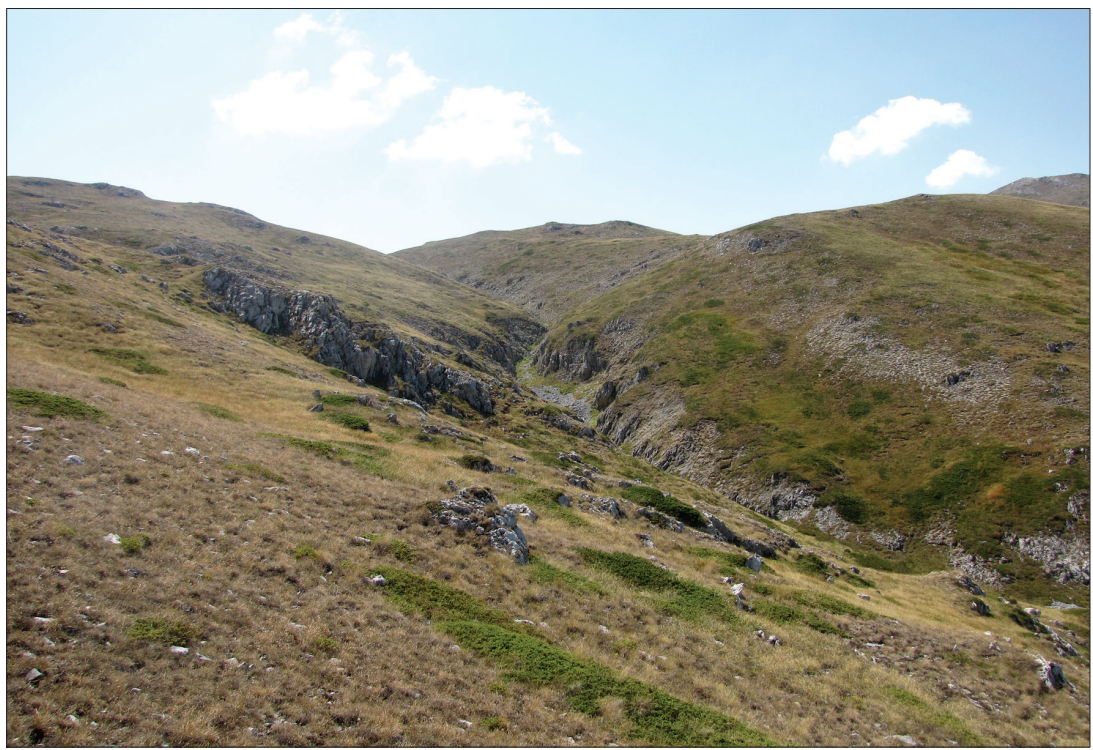




\section{REKONSTRUKCIJA RAVNOVESNE MEJE VIŠKA ZADNJE POLEDENITVE}

Snežna meja (angl. snow line, firn line, firn edge ali annual snow line) je meja med firnom in ledom na ledeniškem površju in jo določimo na osnovi opazovanj ob koncu sezone taljenja (Cuffey, Paterson, 2010). Ravnovesna meja (angl. equilibrium line) pa je meja, na kateri je masna bilanca enaka nič (Porter, 2000), oziroma nadmorska višina, kjer sta akumulacija in ablacija ledu v ravnovesju (Benn, Evans, 1998). Čeprav ravnovesna in snežna meja na toplih ledenikih v povprečju sovpadata, je izraz 'snežna meja' pogosto napačno uporabljen v pomenu 'ravnovesna meja'. Pri študijah masne bilance in dinamike ledenikov ter lokalne klime je pravilneje uporabljati podatek o nadmorski višini ravnovesne meje. Današnjo ravnovesno mejo lahko določimo na podlagi neposrednih meritev masne bilance na ledenikih. Masne bilance na nekdanjih ledenikih ne moremo natančno določiti, zato obstajajo različne morfometrične metode za izračun paleo-ravnovesne meje.

Höferjeva metoda (1879), pri kateri je ravnovesna meja aritmetična sredina med srednjo višino gorskega grebena in spodnjo mejo ledenika, je ena izmed najenostavnejših metod določevanja ravnovesne meje nekdanjih ledenikov. Preprosta metoda je še vedno v uporabi (Bognar, Prugovečki, 1997; Bognar, Faivre, Pavelić, 1991), a velja za manj zanesljivo. Njeno uporabo je mogoče upravičiti le v primeru, ko nimamo na razpolago dovolj natančnih topografskih podatkov.

Z razvojem metodologije paleoklimatskih preučevanj so prišle v uporabo tehnično bolj zahtevne metode določevanja ravnovesne meje nekdanjih ledenikov, ki posledično zahtevajo natančnejše topografske podatke. Med tovrstne metode spadajo metoda obtežene površine ledenika (angl. area-weighted mean-altitude method; Sissons, 1974), metoda relativne velikosti akumulacijskega dela ledenika (angl. accumulation area ratio method; Porter, 2000) ter metoda razmerja masne bilance (angl. balance ratio method; Furbish, Andrews, 1984).

Za izvedbo teh metod je potrebna predhodna rekonstrukcija topografije ledenikov. Ob natančni topografski rekonstrukciji in na osnovi številnih raziskav (Osmaston, 1989; Torsnes in sod., 1993; Meierding, 1982) veljata slednji dve metodi za najbolj zanesljivi metodi določevanja nekdanje ravnovesne meje. Tudi nekatere enostavne metode, kot sta npr. metodi zgornje meje bočnih moren (angl. lateral moraine method; Porter, 2000) ter srednje višine ledenika (angl. median altitude method; Porter, 2000), se lahko izkažejo kot precej natančne. Ti dve metodi, ki sta primerni za dolinski tip poledenitve, smo uporabili za izračun ravnovesne meje viška zadnje poledenitve na Stari Galičici.

Metoda zgornje meje bočnih moren predpostavlja, da pri dolinskem ledeniku v stabilnem stanju zgornja meja bočnih moren sovpada z ravnovesno mejo (Porter, 2000). To je povezano z zakoni ledeniškega toka, saj se led nad ravnovesno mejo premika proti sredini ledenika, pod njo pa v smeri roba ledenika, zato so bočne morene posledično odložene le pod ravnovesno mejo (Andrews, 1975). Ob dobro ohranjenih bočnih morenah nekdanjih ledenikov predstavlja višina njihovih zgornjih mej sprejemljiv približek nekdanje ravnovesne meje (Porter, 2000).

Medtem ko je lahko določevanje ravnovesne meje s to metodo nenatančno zaradi presedimentiranosti morenskega gradiva ali možnosti, da se bočne morene tik pod ravnovesno mejo sploh niso odložile (Meierding, 1982; Hawkins, 1985), pa se za metodo srednje višine 
ledenika že v osnovi domneva, da precenjuje vrednosti ravnovesne meje (Nesje, Dahl, 2000). Ta metoda temelji na predpostavki, da je meja ledeniškega firna v zmernih geografskih širinah ob koncu ablacijskega obdobja navadno na polovici ledenika, kar predstavlja približek nekdanje ravnovesne meje (Porter, 2000). Spodnjo mejo ledenika se določi relativno enostavno, in sicer na podlagi čelnih moren ali rečno-ledeniških vršajev. Določevanje zgornje meje nekdanjega ledenika na območju krnice pa je precej bolj subjektivno, kar lahko pripelje do napake od deset do nekaj sto metrov (Porter, 2000). V naši raziskavi je bila zgornja meja nekdanjega ledenika določena na višini 20-30 metrov pod obodom krnice, na osnovi verjetne globine za pretvorbo snega v led. To vrednost so uporabili pri rekonstrukciji krniških in dolinskih ledenikov v mnogih britanskih raziskavah (npr. Gray, 1982; Shakesby, Matthews, 1993; Wilson, Clark, 1998; Carr, 2001) in je sprejemljiva, kadar nimamo druge možnosti za določitev zgornje meje nekdanjega ledenika.

$\mathrm{Na}$ preučevanem območju Stare Galičice smo identificirali različne tipe poledenitve. Ravnovesno mejo viška zadnje poledenitve smo določili le za dolinski ledenik v severozahodnem delu Stare Galičice, za katerega smo s terenskim delom pridobili dovolj natančne morfometrične podatke. Izvorno območje tega ledenika je bilo v dveh krnicah, delno se je napajal še z južneje ležečega ledenega pokrova, zato ga lahko uvrstimo med odtočne ledenike. Ledeniki z več akumulacijskimi območji, ki se združijo pod ravnovesno mejo in tvorijo skupni zaključek, imajo neodvisen režim masne bilance zaradi samostojnih akumulacijskih območij (Hughes, 2004). V tem primeru izračunamo ravnovesno mejo ločeno za posamezne dele ledenika. To dosežemo z razdelitvijo spodnjega območja ledenika na podlagi relativnega deleža akumulacijskega dela posameznega ledenika.

Na podlagi tega smo pri izračunih ravnovesne meje dolinski ledenik na Stari Galičici obravnavali kot dva ločena ledenika. Po metodi zgornje meje bočnih moren je imel ledenik z izvornim območjem v severnejši, nižje ležeči krnici ravnovesno mejo na nadmorski višini 1790 m, po metodi srednje višine ledenika pa na nadmorski višini 1780 m. Ravnovesno mejo ledenika, ki je imel izvorno območje v višje ležeči krnici, smo po metodi zgornje meje bočnih moren določili na nadmorski višini 1860 m in po metodi srednje višine ledenika na nadmorski višini 1855 m. Povprečna nadmorska višina ravnovesne meje ob višku zadnje poledenitve na Stari Galičici se torej giblje v razponu od 1780 do 1860 m. Kolčakovski (1996) je ugotovil, da je bila pleistocenska snežna meja na območju Stare Galičice na nadmorski višini med 1750 in $1900 \mathrm{~m}$.

Ravnovesno mejo ob višku zadnje poledenitve na Stari Galičici smo izračunali le za dolinski ledenik, katerega krnici imata severovzhodno ekspozicijo. Izračunana meja predstavlja lokalno najnižjo ravnovesno mejo. Na severni polobli se ravnovesna meja namreč spusti najnižje prav na severovzhodnih ekspozicijah, kjer je količina sončnega obsevanja najmanjša, zaradi prevladujočih jugozahodnih vetrov pa se na teh ekspozicijah nabere največ snežnih padavin (Benn, Evans, 1998).

\section{SKLEP}

Geomorfološko preučevanje Stare Galičice smo opravili z namenom rekonstrukcije obsega viška zadnje poledenitve in takratnih paleoklimatskih značilnosti. Ugotovili smo, da je bil obseg poledenitve bistveno večji kot ga navaja dosedanja literatura (Kolčakovski, 
1996). Poledenitev ni bila omejena le na dva krniška ledenika v severnem delu Stare Galičice, ampak je bil poledenel celoten vršni del planine, na severnih in jugovzhodnih pobočjih pa so bili odtočni ledeniki, ki so na severni strani segali vse do prevala Ponce. Prav tako smo izračunali ravnovesno mejo ledenikov med 1780 do 1860 m nadmorske višine, dosedanja literatura pa je ravnovesno mejo postavljala med 1750 in $1900 \mathrm{~m}$.

Površje Stare Galičice je bilo v pleistocenu izrazito preoblikovano z ledeniškim delovanjem. Zaradi krasa po koncu pleistocena ni bilo erozijskih procesov, ki bi bistveno preoblikovali površje in presedimentirali ledeniške nanose, zato so se ohranile oblike, kakršne so bile ob koncu ledeniškega preoblikovanja.

Ledeni pokrov, ki je prekrival osrednji del Stare Galičice, je dosegel debelino več kot $100 \mathrm{~m}$. Na podlagi ledeniških grbin je bilo ugotovljeno, da se je led stekal proti severu. Podledeniški potoki so ustvarili številna korita, dna kotanj pa je v času poledenitve zapolnil finozrnat material. Ledeni pokrov se je stekal v dva odtočna ledenika na severu, del ledu je odtekal tudi proti jugu. Vzhodni odtočni ledenik je bil v zgornjem delu debel okoli $70 \mathrm{~m}$ in je segal do nadmorske višine 1540 m na prevalu Ponce, kjer so odloženi zadnji čelnomorenski nasipi. Predledeniški tokovi so izpred ledenika odtekali na vzhod v smeri Prespanskega jezera, kar kaže večji rečno-ledeniški vršaj na pobočju nad Prespanskim jezerom pri vasi Leskoec. Zahodni odtočni ledenik se je dodatno napajal iz dveh manjših krnic na zahodni strani doline. Debelina odtočnega ledenika je bila v višini krnic okoli $80 \mathrm{~m}$. Prav tako kot vzhodni je tudi ta segal do prevala Ponce, kjer so na nadmorski višini 1520 m odloženi čelnomorenski nanosi. Predledeniški tokovi so odtekali po strmem erozijskem jarku proti zahodu in nad vasjo Trpejca ob Ohridskem jezeru odložili obsežen rečno-ledeniški vršaj.

$\mathrm{Na}$ podlagi morfografske in morfometrične analize sledov poledenitve smo izdelali rekonstrukcijo ravnovesne meje ledenikov ob višku zadnje poledenitve za območje Stare Galičice. Uporabili smo metodi zgornje meje bočnih moren in srednje višine ledenika. Zaradi kombinacije platojskega in odtočnega tipa poledenitve so bili za paleoklimatsko rekonstrukcijo uporabni le podatki zahodnega odtočnega ledenika. Ker gre za ledenik z ločenimi akumulacijskimi območji, smo izračunali ravnovesno mejo za posamezne dele ledenika. Obravnavali smo ga kot dva ločena ledenika. Ledenik z izvornim območjem v nižje ležeči, severnejši krnici je imel po metodi zgornje meje bočnih moren ravnovesno mejo na 1790 m nadmorske višine, po metodi srednje višine ledenika pa na $1780 \mathrm{~m}$. Na ledeniku z izvornim območjem v višje ležeči krnici se je ravnovesna meja nahajala na nadmorski višini 1860 m (po metodi zgornje meje bočnih moren) oziroma na nadmorski višini $1855 \mathrm{~m}$ (po metodi srednje višine ledenika). Torej je bila ravnovesna meja na pobočjih s severno ekspozicijo na nadmorski višini okoli $1840 \mathrm{~m}$.

\section{Literatura in viri}

Andrews, J. T., 1975. Glacial systems: An approach to glaciers and their environments. North Scituate, Duxbury Press, 191 str.

Anđelković, M., 1988. Geologija Jugoslavije. Tektonika. Beograd, Građevinska knjiga, 692 str.

Benn, D. I., Evans, D. J. A., 1998. Glaciers and glaciation. London, Arnold, 734 str. 
Bognar, A., Faivre, S., Pavelić, J., 1991. Tragovi oledbe na Sjevernom Velebitu. Geografski glasnik, 53, 1, str. 27-39.

Bognar, A., Prugovečki, I., 1997. Glaciation traces in the area of the Risnjak Mountain massif. Geologia Croatica, 50, 2, str. 269-278.

Carr, S., 2001. A glaciological approach for the discrimination of Loch Lomond stadial landforms in the Brecon Beacons, South Wales. Proceedings of the Geologists' Association 112, 3, str. 253-262.

Cuffey, K. M., Paterson, W. S. B., 2010. The physics of glaciers, 4th edition. Burlington, Elsevier, 693 str.

Furbish, D. J., Andrews, J. T., 1984. The use of hypsometry to indicate long-term stability and response of valley glaciers to changes in mass transfer. Journal of glaciology, 30, 105, str. 199-211.

Gray, J. M., 1982. The last glaciers (Loch Lomond Advance) in Snowdonia, North Wales. Geological Journal, 17, 2, str. 111-133.

Hawkins, F., 1985. Equilibrium-line altitudes and palaeoenvironments in the Merchants Bay area, Baffin Island, N.W.T., Canada. Journal of glaciology, 31, 109, str. 205-213.

Höfer, H. V., 1879. Gletscher und Eiszeitstudien. Sitzungsberichte der Akademie der Wissenschaften in Wien, Mathematisch-Naturwissenschaftliche Klasse, 79, str. 331-367.

Hughes, P. D., 2004. Quaternary glaciation in the Pindus Mountains, Northwest Greece. Doktorsko delo. Cambridge, Darwin College, University of Cambridge, 341 str.

Kolčakovski, D., 1990. Pojave visokoplaninskog krasa na teritoriji SR Makedonije i potrebe njegovog proučavanja. Četvrti skup geomorfologa Jugoslavije, str. 95-113.

Kolčakovski, D., 1995. Sliznati blokovi - prilog kon proučuvanjeto na periglacijalniot reljef vo Republika Makedonija. Geografski razgledi, 50, str. 125-133.

Kolčakovski, D., 1996. Geomorfološki karakteristiki na visokoplaninskiot predel na Stara Galičica. Geografski razgledi, 51, str. 53-65.

Manaković, D., Andonovski, T., Kolčakovski, D., 1993. Podzemni karstni formi vo nacionalniot park Galičica. Godišen zbornik na PMF, 31-32, str. 37-71.

Meierding, T. C., 1982. Late Pleistocene equilibrium-line altitudes in the Colorado Front Range: A comparison of methods. Quaternary research, 18, 3, str. 289-310.

Nesje, A., Dahl, S. O., 2000. Glaciers and environmental change. London, Arnold, 203 str.

Osmaston, H., 1989. Glaciers, glaciations and equilibrium line altitudes on Kilimanjaro. V: Mahaney, W. C. (ur.). Quaternary and environmental research on East African Mountains. Rotterdam, Balkema, str. 7-30.

Osnovna geološka karta SFRJ. Lista Ohrid in Podgradec. 1977. 1 : 100.000. Beograd, Zvezni geološki zavod.

Porter, S. C., 2000. Snowline depression in the tropics during the Last Glaciation. Quaternary science reviews, 20, 10, str. 1067-1091.

Shakesby, R. A., Matthews, J. A., 1993. Loch Lomond Stadial glacier at Fan Hir, Mynydd Du (Brecon Beacons), South Wales: Critical evidence and palaeoclimatic implications. Geological Journal, 28, 1, str. 69-79.

Sissons, J. B., 1974. A Late-glacial ice cap in the central Grampians, Scotland. Transactions of the Institute of British Geographers, 62, str. 95-114. 
Stojadinković, Č., 1968. Geneza na litoralniot reljef na bazenot od Ohridskoto Ezero i negovite tektonski i abrazioni elementi. Godišen zbornik na PMF, 16, str. 103-127.

Točkovski, V., 1970. Pešteri na Galičica. Peti jugoslovenski speleološki kongres, str. 161-172. Torsnes, I., Rye, N., Nesje, A., 1993. Modern and Little Ice Age equilibrium-line altitudes on outlet valley glaciers from Jostedalsbreen, western Norway: An evaluation of different approaches to their calculation. Arctic and Alpine research, 25, 2, str. 106-116.

Wilson, P., Clark, R., 1998. Characteristics and implications of some Loch Lomond Stadial moraine ridges and later landforms, eastern Lake District, northern England. Geological Journal, 33, 2, str. 73-87.

Zikov, M., 1987. Geomorfološki osobenosti, nivna valorizacija i kategorizacija za prostornoto ureduvanje na nacionalniot park Galičica. Geografski razgledi, 26, str. 181-190.

\section{REMNANTS OF PLEISTOCENE GLACIATION ON STARA GALIČICA MOUNTAIN, MACEDONIA}

\section{Summary}

The Stara Galičica Mountain is situated along the Albanian-Macedonian border between Lakes Prespa and Ohrid. Its surface was highly reshaped by glacial processes during the Pleistocene. The research was concerned with the extent of glaciers during the Last Glacial Maximum and with the reconstruction of paleoclimatic conditions. Our research during fieldwork with a group of geography students from the Ljubljana's Department of Geography revealed that the extent of the glaciation was larger than described in previous literature (Kolčakovski, 1996). It was not limited solely to two cirque glaciers as previous research suggested. A quite extensive ice cap was covering the whole high mountain plateau on the top of Stara Galičica and two outlet glaciers were descending from it towards the north.

Due to karstic character of the area, there were no significant processes, which would erode or redeposit glacial features after the end of Pleistocene glaciation. In the area of former ice cap numerous roche moutonnées, ground moraines and subglacial gullies are preserved. The thickness of the ice cap was estimated to about $100 \mathrm{~m}$. The thickness of the eastern outlet glacier was about $70 \mathrm{~m}$ in its upper section. Terminal accumulations were identified at the altitude of $1540 \mathrm{~m}$ a.s.l. The western outlet glacier was descending towards the north as well, merging with two short cirque glaciers. Its thickness at the altitude of the cirques was estimated to about $80 \mathrm{~m}$. It ended at the altitude of $1520 \mathrm{~m}$ a.s.1.

Concerning paleoclimatic characteristics, only the equilibrium line altitude for the Last Glacial Maximum was determined in the western outlet glacier valley. Based on the lateral moraine method and the median altitude method, the equilibrium line altitude as well as snow line were established at $1840 \mathrm{~m}$ a.s.l.

(Translated by authors) 